\title{
8
}
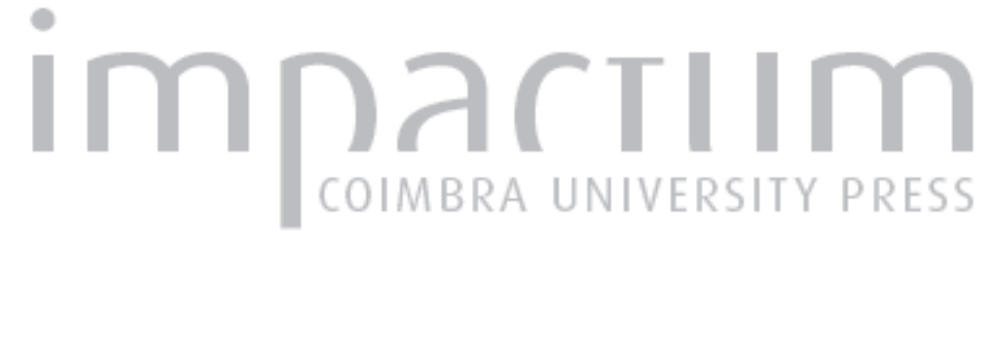

At Risk - natural hazards, people's vulnerability and disasters: um livro importante Autor(es): $\quad$ Monteiro, Ana

Publicado por: Associação Portuguesa de Riscos, Prevenção e Segurança

URL persistente:

URI:http://hdl.handle.net/10316.2/40199

DOI:

DOl:https://doi.org/10.14195/1647-7723_1_7

Accessed : $\quad$ 26-Apr-2023 13:22:57

A navegação consulta e descarregamento dos títulos inseridos nas Bibliotecas Digitais UC Digitalis, UC Pombalina e UC Impactum, pressupõem a aceitação plena e sem reservas dos Termos e Condições de Uso destas Bibliotecas Digitais, disponíveis em https://digitalis.uc.pt/pt-pt/termos.

Conforme exposto nos referidos Termos e Condições de Uso, o descarregamento de títulos de acesso restrito requer uma licença válida de autorização devendo o utilizador aceder ao(s) documento(s) a partir de um endereço de IP da instituição detentora da supramencionada licença.

Ao utilizador é apenas permitido o descarregamento para uso pessoal, pelo que o emprego do(s) título(s) descarregado(s) para outro fim, designadamente comercial, carece de autorização do respetivo autor ou editor da obra.

Na medida em que todas as obras da UC Digitalis se encontram protegidas pelo Código do Direito de Autor e Direitos Conexos e demais legislação aplicável, toda a cópia, parcial ou total, deste documento, nos casos em que é legalmente admitida, deverá conter ou fazer-se acompanhar por este aviso.

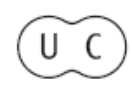




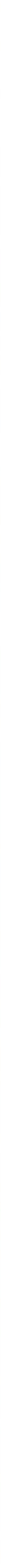


terminou com um estágio no domínio dos riscos em empresas ou colectividades com preocupações nessa matéria.

A pedido da Universidade de Paris I, o Ministério francês da Educação Nacional criou nessa mesma Universidade, em 1993/94, um DESS ("Diplôme d'Etudes Supérieures Spécialisées", ou seja, um diploma nacional com objectivos profissionais). $O$ anterior DESUP ganhou, pois, um novo estatuto e passou a intitular-se "Gestion globale des risques et des crises".

Manteve-se a estrutura geral do Curso, embora com algumas modificações de pormenor no interior dos módulos de ensino. Por exemplo, os estudos começaram no campo com um estágio em Frioul, no Mediterrâneo.

O estágio para estudo de casos em Portugal verificou-se de novo no final do primeiro semestre decorrido em Paris e foi da nossa responsabilidade tendo-se intitulado "Risques et gestion de risques au Portugal". Tal como no ano anterior, logo após a chegada do grupo (agora 11 estudantes franceses (9) e africanos de países francófonos (2), acompanhados por dois professores, Lucien Faugèrese Jean-François
Noël), foi o primeiro contacto com osriscos tectónicos, climatológicos e hidrológicos de Lisboa (31 de Janeiro de 1994). Osegundo dia correspondeuà visita demorada a Coimbra e o terceiro ainda se relacionou com a cidade já que se fez uma viagem de estudo pelas proximidades (Lousã, Aguieira, Montemor-o-Velho e Figueira da Foz) referindo riscos de incêndios florestais, riscos climatológicos e problemas de erosão acelerada e cheias. $O$ quarto dia voltou a dedicar-se a Coimbra tendo o grupo sido recebido pelo Governador Civil do Distrito de Coimbra, Eng. Pedroso de Lima. No quinto dia os alunos continuaram em Coimbra.

Desta vez, privilegiamos o estudo mais aprofundado, o contacto pessoal e a descoberta pelos próprios alunos. Para além da observação, fizeram-se diversos inquéritos. Entre as personalidades que receberam os estudantes não pode deixar de se referiro Vereador da Câmara Municipal de Coimbra, Dr. Henrique Fernandes, que lhes facultou numerosos documentos relativos a riscos urbanos.

Na sequência deste estágio, veio a ser feito, em trabalho de grupo, um interessante relatório de 47 páginas policopiadas, intitulado "Coimbra: ville multidimensionelle".

\section{At Risk - natural hazards, people's vulnerability and disasters. Um livro importante.}

\section{Ana Montelro}

Recomendamos vivamente a leitura deste livro de Pier Blaikie, Terry Canvon, Ian Davis e Ben W ISNER, editado por Routledge, Londres, 1994, 284 p., 23 figuras e 4 tabelas, a todos os que profissional ou pessoalmente, não adoptando uma atitude ecocênctrica sobre o nosso papel no Ecossistema, acreditam que, se aguçarmos o engenho, a arte e, atrevemo-nos a acrescentar, o conhecimento, poderemos minimizar consideravelmente os impactes provocados por grande parte daquilo que comummente se designam Catástrofes Naturais.

Pretendendo contribuir, como maisum documento de reflexão, na Década Internacional da Redução das Catástrofes Naturais em que se insere, esta obra discute e questiona, recorrendo a variadíssimos exemplos, as razões pelas quais os efeitos gerados por muitas Catástrofes Naturais são grandemente amplificados por Acção Antrópica.

Defendem os autores que a maioria daquilo que vulgarmente designamos Catástrofes Naturais, embora sejam desencadeadas e despoletadas por uma causa Natural vêem posteriormente a magnitude dos seus impactes aumentada ou diminuida consoante o meio socio-económico e político em que ocorrem.

O exemplo recordado pelos autores, logo no primeiro capítulo intitulado: 1 - "The Challenge of Disasters and Our Approach", a propósito da classificação de "Class-Quake" dada ao sismo que em 4/2/1976 fez tremera Guatemalae em que morreram 22000 pessoase mais de 90000 ficaram sem alojamento, explicando que esta designação se deveu ao facto de grande parte das vítimas pertencer ao grupo socialmente mais desfavorecido, com menos recursos e alojado obviamente em áreas de maior risco, ajuda-nos, 
desde início, a perceber o argumento central do livro: o grau de vulnerabilidade da população é determinante para perceber qualquer desastre e, portanto, para o prevenir e/ou mitigar.

Depois de esclarecidos quanto ao argumento central da obra, somos confrontados, no capítulo seguinte intitulado "Disaster Pressure and Release Model", com aquilo que os autores apelidam de cadeia explicativa de uma catástrofe. Definindo o grau de Risco como o resultado final da combinação dos efeitos da catástrofe e da vulnerabilidade, demonstram como a magnitude das consequências está na estreita dependência não só das características do suporte físico, mas também da armadura social, económica e política existente na área em que ocorre um determinado fenómeno natural (seca, cheia, ciclone, tufão, erupção vulcânica, sismo, etc.).

Tendo identificado, por diversas vezes, durante a anterior exposição, que a maior ou menor capacidade da população em aceder aos recursos é determinante na minimização da vulnerabilidade e, portanto, na gestão das adversidades, surgem no $3^{\circ}$ capítulo intitulado: "Access to Resources and Coping in Adversity", cerca de 25 páginas dedicadas à apresentação de alguns modelos de diagnóstico de intervenção deste tipo de adversidades indispensáveis para a definição de qualquer estratégia de minimização da vulnerabilidade.

A segunda parte do livro - "Vulnerability and
Hazard Types"- inventaria, descreve e analisa algumas das catástrofes que foram amplamente moticiadas nos últimos anos, explicando algumas das estratégias que poderiam ter minimizado as suas repercussões. Os exemplos estão organizados em cinco grupos que correspondem a outros tantos capítulos: 4 - Fome, 5 - Acidentes Biológicos, 6 - Cheias, 7 - Tempestades, 8 - Sismos, Vulcões e Deslizamentos.

A terceira e última parte agrega os dois últimos capítulos cujo objectivo é dissecar um conjunto de acções capazes de reduzir significativamente o grau de risco da população e dos lugares quando ocorre um qualquer destes fenómenos naturais. Enunciamse, primeiro, alguns dos princípios elementares para gerir e operacionalizar a recuperação e reabilitação de uma área afectada por uma catástrofe e, depois, um conjunto de outros princípios de carácter preventivo que os decisores deveriam adoptar para diminuir a vulnerabilidade.

Para além do interesse que pretendemos ter demonstrado, com esta brevíssima descrição, sobre a forma como esta temática é abordada ao longo do livro, gostaríamos de acrescentar que dele também fazem parte um vasto e interessante conjunto de mapas de risco, estatísticas e descrições pormenorizadas do cenário criado por algumas catástrofes naturais, cuja utilidade científica e pedagógica não poderemos deixar de mencionar. 